\section{From hillside to laboratory}

\section{London}

LESs than two weeks ago, botanist Riadh Dinha Francis and his family were living in the Shemdinly refugee camp on the Iraqi/ Turkish border. This week, following a concerted effort by British scientists and diplomats, he is in Sheffield, ready to resume research interrupted by the war in the Persian Gulf.

Francis owes his rescue to a chance appearance on British national television. Interviewed for Channel 4's nightly news bulletin in April, he was recognized by Terry Croft, manager of the Department of Animal and Plant Sciences at the University of Sheffield. Francis had completed his doctorate at Sheffield in 1985, and then returned to Salahaddin University in Arbil, Iraq. He hoped to return to Britain, however, and before the outbreak of the war, he had applied for a Royal Society fellowship to continue his research at Sheffield.

After spotting Francis on the broadcast, Croft asked the Royal Society and Channel from Turkey by the Royal Air Force. mountains," he says.

\section{Forensic reform needed now}

\section{London}

IN the wake of the celebrated release of the Birmingham Six, experts are saying that Britain needs to rethink the way it provides forensic science testimony to the courts.

In March, the conviction of the Birmingham Six was overturned after the forensic evidence used to convict the six Irishmen accused of two terrorist bombings in Birmingham in 1974 was discredited. That case has prompted a Royal Commission that will consider reforms to the British judicial

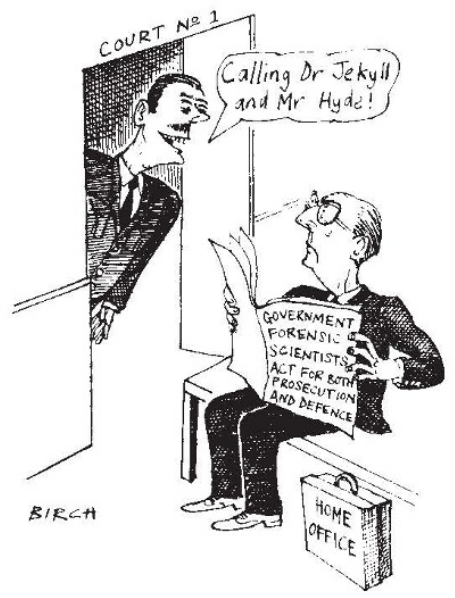

system. But the Royal Commission is expected to take several years to gather its evidence, and at least one forensic expert says that reform of the forensic science profession is needed much sooner.

Angela Gallop from Forensic Access, one of only a handful of respected British independent forensic scientific consultants, told a meeting at the Royal Society this week that 4's science correspondent, Andrew Veitch, to help find the Iraqi researcher and bring him to Britain. Several weeks later, after intense behind-the-scenes effort by British diplomats, Francis and his family were flown

Francis, an Iraqi Christian, says that most of Salahaddin University's staff and its 6,000-7,000 students fled from Arbil when the Iraqi army advanced against the Kurdish rebels: "Many of my students are on the

Salahaddin, the only university in the Kurdish region of Iraq, has effectively been closed since the beginning of the Gulf War, Francis says. During the Kurdish uprising, he reports, the college of education was "completely destroyed" by Kurdish rebels venting their anger against the Baghdad regime. The rest of the university is intact, he says, but he doubts that many of its staff will ever return.

Conditions in the refugee camps on the Iraqi/Turkish border were beginning to improve by the time he left, Francis says,

lawyers representing suspected criminals in British courts must often prepare their cases without adequate scientific advice. Unless the many "cowboys" operating as independent forensic scientists are regulated, Gallop said, the treatment of scientific evidence in British courts will remain biased in favour of the prosecution.

The problem with the present British system, Gallop said, is that the same Home Office scientists who have been intimately involved in a police investigation are then asked to stand in court and give dispassionate scientific evidence. Asking Home Office forensic scientists to "pick holes" in their own evidence, said Gallop, is like "expecting a hound which has just caught a hare ... to give it the kiss of life".

Independent forensic scientists, Gallop said, are vital to help prepare defence cases, and to give evidence in court. In the absence of regulation, any person with a scientific background can set himself up as an independent forensic science consultant.

Gallop called on the Forensic Science Society and the Law Society to rid the profession of such unqualified practitioners.

Home Office and police laboratories now have a virtual monopoly in training Britain's forensic scientists, and too few scientists leave the Home Office to work independently, Gallop said. The reason, she said, is the long delays between cases coming to court and independent forensic scientists getting paid. The legal fees for many defendants are paid by the state, through the system of Legal Aid. But this often takes many months, or even years to process.

Peter Aldhous although the distribution of food and medicines was still chaotic. When he was interviewed in April, Francis and his family had not eaten for three days.

Francis also corroborates stories that have emerged from Kuwait of the theft of scien-

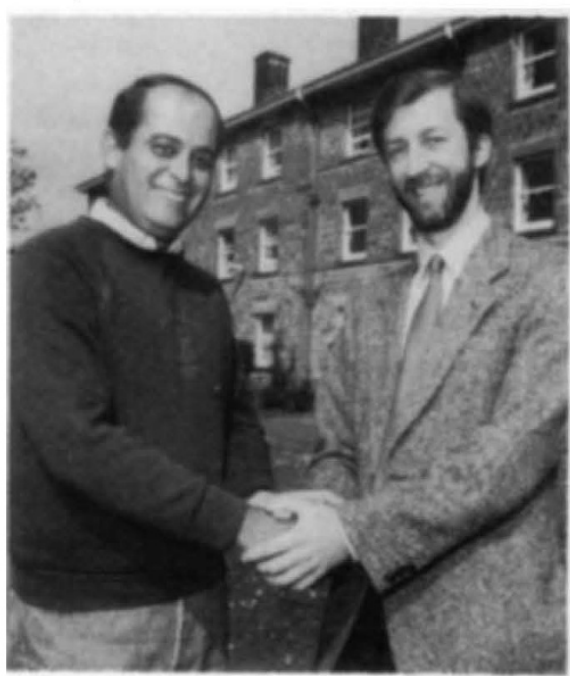

Riadh Dinha Francis with Terry Croft, his rescuer.

tific equipment during the Iraqi occupation. "We have seen lorries filled with equipment from Kuwait University," he says. But he adds that the theft was organized from Bagh$\mathrm{dad}$ - the vice-chancellor and chancellor of Salahaddin were not involved.

Peter Aldhous

\section{SPACE}

\section{First Briton hits orbit \\ London}

Ат 15:50 Moscow time on 18 May, Helen Sharman blasted off from the Baikonur launch site in the republic of Kazakhstan to become the first Briton in space. Two days and more than $\mathbf{3 0}$ orbits of the Earth later, the Soyuz capsule carrying Sharman and her two Soviet colleagues docked successfully with the Mir space station. Sharman will spend six days aboard Mir, conducting experiments devised by scientists working for the Soviet space programme, before returning to Earth with two Soviet cosmonauts, who have been working on board Mir for the past six months.

The Anglo-Soviet Juno mission, which aimed to put a British astronaut and a roster of British microgravity experiments into space, came near to collapse last year when commercial sponsors failed to come forward. The mission was saved when its original financial backers, the Londonbased Moscow Narodny Bank, offered to pay the Soviets an undisclosed sum to secure a flight for a British astronaut. The sum involved is thought to be much less than the mission's original estimated cost of $£ 16$ million. At a pre-launch press conference, Soviet journalists are reported to have expressed dissatisfaction at the Soviet Union 'subsidizing' Sharman's flight. Peter Aldhous 